\title{
Interaction of quaternary ammonium ionic liquids and bacterial cell membrane
}

\author{
Tomasz Cłapa ${ }^{2}$, Dorota Narożna², Cezary Odrzygóżdż², Jakub Michalski², Damian Nikodem², Krzysztof \\ Szubiczuk ${ }^{2}$, Marek Selwet ${ }^{1}$ \\ ${ }^{1}$ Department of General and Environmental Microbiology, Poznań University of Life Sciences, Szydłowska 50, Poznań, Poland \\ ${ }^{2}$ Department of Biochemistry and Biotechnology, Poznań University of Life Sciences, Dojazd 11, Poznań, Poland \\ Corresponding author: tom.clapa@gmail.com \\ DOI: 10.31708/spi3.2018/clap.cns18
}

\section{Introduction}

The ionic liquids (ILs) still remain in interest of the many of scientific and industrial laboratories. They exhibit unique properties due to both ionic character and low melting point. They are characterized by nonflammability, high polarity and ionic conductivity (Markiewicz et al., 2014; Pernak et al., 2006). ILs also poses antimicrobial properties, e.g. growth inhibition, cyto- and genotoxicity. However, the studies that try to characterize Ils mostly are mechanistic and do not bring the answer how ionic liquids interacts with cell composites, e.g. proteins or cell membrane. It is very important because such compounds might influence of cell structures or the cell itself. Additionally, it turned out, that the quaternary ammonium salts can modify the electrokinetic potential of Gram-negative bacterial outer membrane. Thus, the question about possibility to adapt bacterial cells arises (Borkowski et al., 2016; Pernak, Sobaszkiewicz, \& Mirska, 2003).

For the synthesis of ionic liquids, new precursors have been used lately, even those inspired by nature, e.g. theophylline. This compound can be found in leaves and beans of cocoa and its high concentration protects plants from pathogenic bacteria, fungi and insects. Such properties can suggest that it could be an active part of ILs, thus could influence on bacteria growth and viability. Increasing chain length causes the increase of toxicity, however this relationship is not true at chain length $\mathrm{C} 18$. The toxicity of $\mathrm{C} 18 \mathrm{~T}$ is significantly lower in relation to $\mathrm{C} 16 \mathrm{~T}$ and $\mathrm{C} 14 \mathrm{~T}$. This phenomenon concerning a lot of ionic liquids comprising alkyl substituents is known as "cut-off" effect and is distinctly observed mainly at Gramnegative bacteria. It was also shown that some of the Ils can significantly modify surface charge of the external lipid membrane of Gram-negative bacteria which can cause the agglomeration of bacteria as well as the adsorption of negatively charged particles or compounds (Borkowski et al., 2017; Borkowski, Gutowski, Syczewski, Cłapa, \& Czerwonka, 2018).

The aim of the presented studies was the adaptation of Escherichia coli to increasing concentration of tetradecyltrimethylammonium theophyllinate. After adaptation, the bacteria were examined to recognition of changes in cell morphology, lipid and protein composition.

\section{Materials and Methods}

Strains of $E$. coli were cultivated in liquid tryptic soy broth (TSB, Sigma-Aldrich, Sigma-Aldrich Ltd., Poznań Poland). Minimum inhibitory concentration (MIC) and minimum bactericidal concentration (MBC) were estimated using the microtiter plates method, using sterile 96-well plates, and based on the measurements of dehydrogenase activity. The zeta (electro kinetic) potential of bacterial cells dispersed in TILs solution at concentration of $100 \mathrm{mg} \mathrm{L}-1$ liquid was determined using the laser Doppler velocimetry method. Fluorescence microscope - live/death staining method was performed by using propidium iodide and acridine orange dyes.

\section{Results and Discussion}

Our results showed how the Gram-negative bacteria can adapt to lethal concentration of quaternary ammonium ionic liquids. There are no doubts that the ionic liquids can affect the properties of bacterial outer membrane that can appear as the changes of electrokinetic potential or membrane permeability. The cultivation of bacteria with ionic liquids led to significant changes of membrane permeability and composition, thus influence on the cell morphology. Based on our experiments the main conclusion can be established. Bacteria can easily adapt to the increasing concentration of toxic quaternary ammonium ionic liquids.

\section{References}

Borkowski, A., Gutowski, Ł., Syczewski, M., Cłapa, T., \& Czerwonka, G. (2018). Adaptation of bacteria Escherichia coli in presence of quaternary ammonium ionic liquids. Ecotoxicology and Environmental Safety, 164, 370-378. https://doi.org/10.1016/j.ecoenv.2018.08.048

Borkowski, A., Kowalczyk, P., Czerwonka, G., Cieśla, J., Cłapa, T., Misiewicz, A., ... Drabik, M. (2017). 


\section{Opplied}

Biosciences

Interaction of quaternary ammonium ionic liquids with bacterial membranes - Studies with

Escherichia coli R1-R4-type lipopolysaccharides.

Journal of Molecular Liquids, 246, 282-289.

https://doi.org/10.1016/j.molliq.2017.09.074

Borkowski, A., Ławniczak, Ł., Cłapa, T., Narożna, D., Selwet, M., Pęziak, D., ... Chrzanowski, Ł. (2016).

Different antibacterial activity of novel

theophylline-based ionic liquids - Growth kinetic

and cytotoxicity studies. Ecotoxicology and

Environmental Safety, 130, 54-64.

https://doi.org/10.1016/j.ecoenv.2016.04.004

Markiewicz, B., Sznajdrowska, A., Chrzanowski, Ł.,

Ławniczak, Ł., Zgoła-Grześkowiak, A., Kubiak, K., ... Pernak, J. (2014). Ionic liquids with a

theophyllinate anion. New Journal of Chemistry,

38(7), 3146-3153.

https://doi.org/10.1039/C4NJ00463A

Pernak, J., Smiglak, M., Griffin, S. T., Hough, W. L., Wilson, T. B., Pernak, A., ... Rogers, R. D. (2006).

Long alkyl chain quaternary ammonium-based ionic liquids and potential applications. Green Chemistry, 8(9), 798-806.

https://doi.org/10.1039/b604353d

Pernak, J., Sobaszkiewicz, K., \& Mirska, I. (2003). Antimicrobial activities of ionic liquids. Green Chemistry, 5(1), 52-56.

https://doi.org/10.1039/b207543c 